Recibido: 21 enero 2014

Aprobado: 13 marzo 2014

\section{URBAN FLOOD CONTROL IN THE NETHERLANDS: A HISTORY*}

Nikki Brand** - Delft University of Technology, The Netherlands
Zandvoort's boulevard in contemporary times Source: Coastal Quality Studio, supplied by author, N. Brand, 2014.

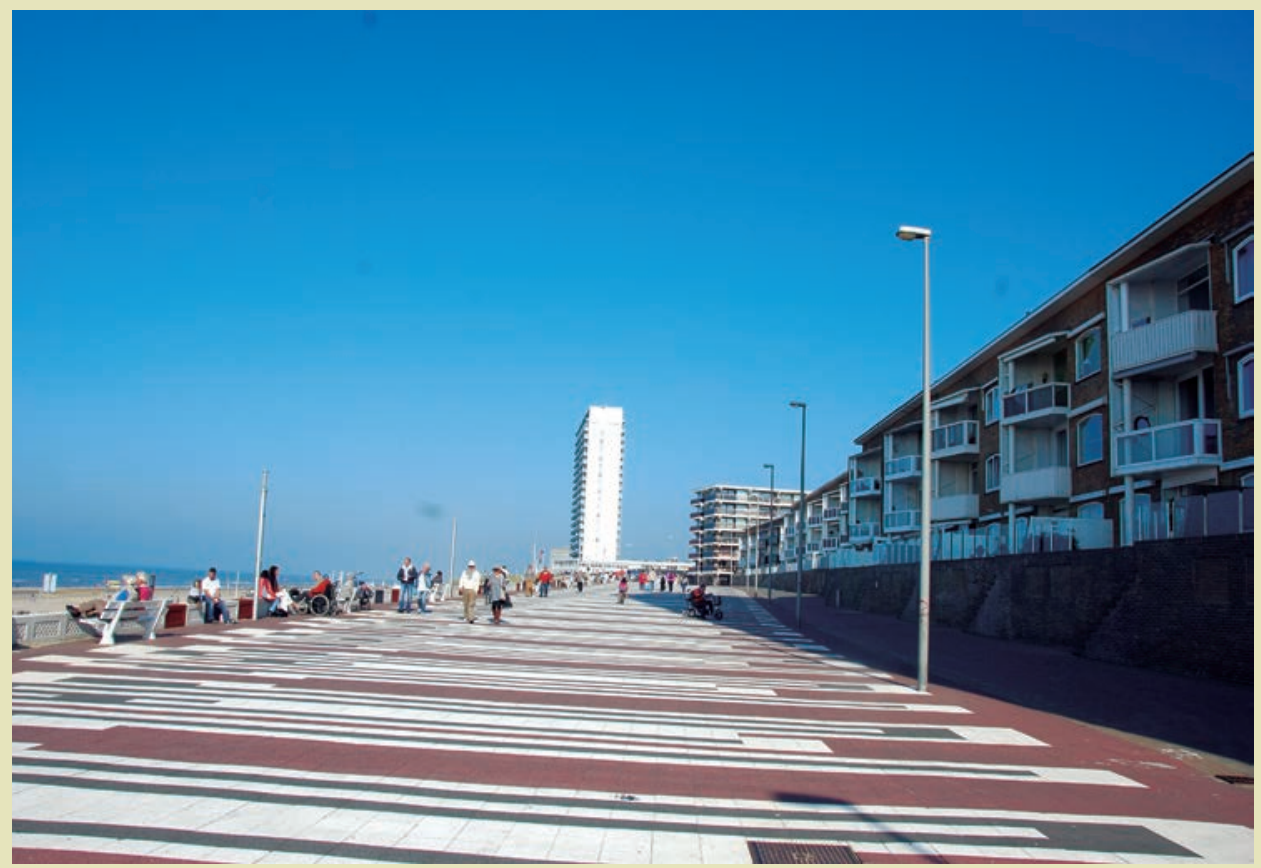

\section{ABSTRACT}

The Netherlands has a long-standing tradition of protection flood. The article investigates how flood control has taken shape over the last two centuries, and addresses the question how this phenomenon influenced the spatial appearance of Dutch waterfronts. The hypothesis underpinning this paper is that centralization of flood control measures in the Netherlands increased the protection level of these waterfronts but also added to the uniformity of coastal resorts. Centralization also decreased the responsiveness of flood control measures to local needs, which explains the contemporary quest for measures catered to local interests in the Netherlands. To do so, the paper explores the major changes in the approach towards flood control since 1800 , and identifies the spatial impact of flood control measures on urban communities. Additionally, it identifies the major drivers for changes in flood protection measures.

\section{KEYWORDS}

Flood protection, Coastal resorts, Netherlands waterfronts 


\section{CONTROL DE LAS INUNDACIONES URBANAS EN LOS PAÍSES BAJOS: UNA HISTORIA}

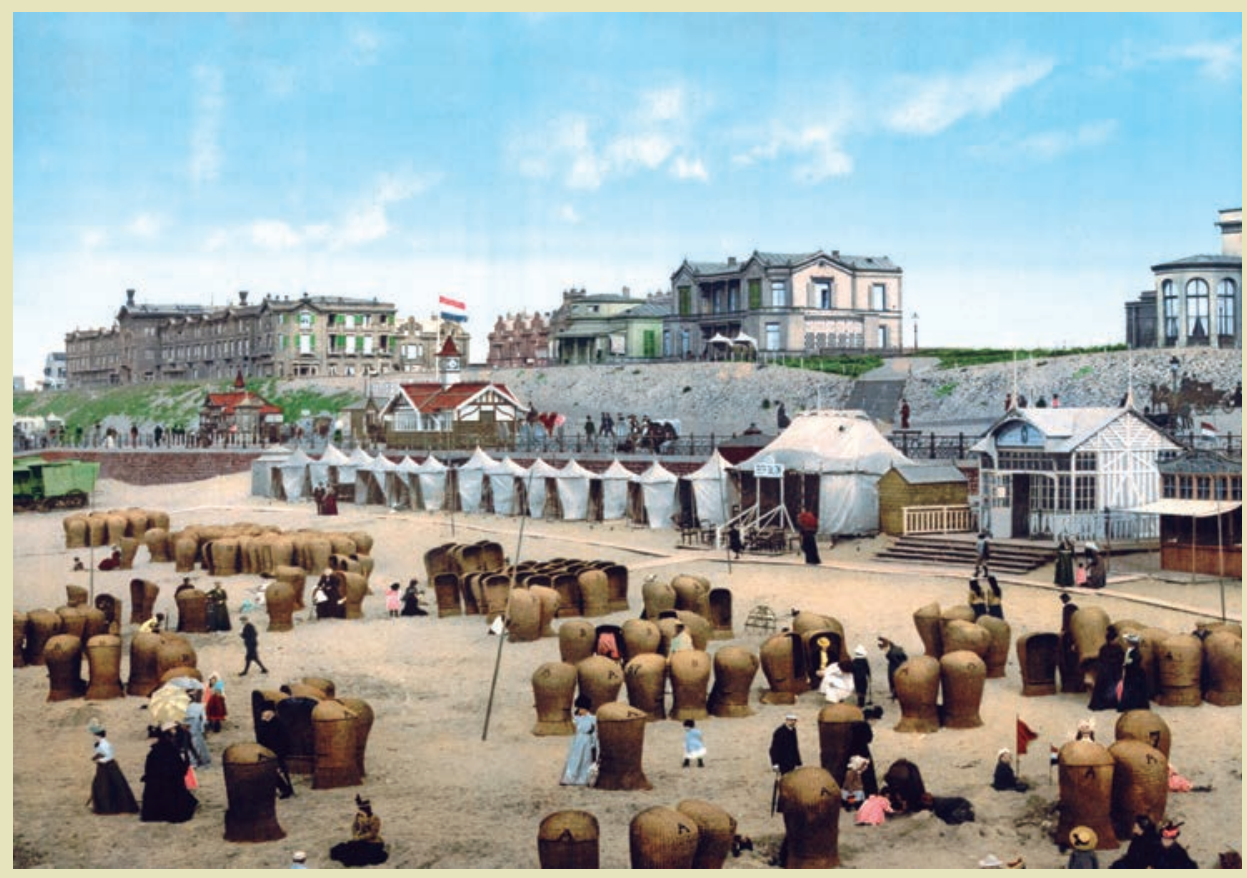

Scheveningen and its boulevard by 1900 Source: LC-DIG-ppmsc-0586I from Library of Congress, Prints and Photographs Division Photochrom Prints Collection

\section{RESUMEN}

Los Países Bajos tienen una tradición de larga data en lo que respecta a la protección contra las inundaciones. Este artículo investiga de qué manera la protección contra inundaciones ha tomado forma durante los dos últimos siglos, y aborda la cuestión de cómo este fenómeno ha influido en el aspecto espacial de frentes de agua holandesas. La hipótesis que sustenta este trabajo es que la centralización de las medidas de protección contra inundaciones en los Países Bajos aumentó el nivel de protección de estos frentes de agua, pero además contribuyó a la uniformidad de los centros turísticos costeros. La centralización también redujo la capacidad de respuesta de las medidas de protección contra las inundaciones a las necesidades locales, lo que explica la búsqueda contemporánea de medidas atentas a estos intereses. Para ello, el documento analiza los principales cambios en el enfoque hacia la protección contra las inundaciones desde 1800 , e identifica su impacto territorial en las comunidades urbanas. Además, identifica los principales impulsores de los cambios en las medidas de protección contra inundaciones.

\section{PALABRAS CLAVE}

Protección de inundaciones, centros turísticos costeros, frentes de agua holandeses. 


\section{INTRODUCTION}

In spite of the obvious necessity of flood control in a country that's below sea level, local communities that have a flood defense within their perimeter do not necessarily welcome spatial interventions on behalf of flood control. Recent fortification measures of a large dike structure in West-Friesland were compared by local citizens with the infamous German Atlantikwall: an extensive system of coastal fortifications, made of concrete and barbed wire, constructed by Nazi Germany in the 1940s.' Such examples demonstrate that an explicit concern exists that flood control measures in the Netherlands are unresponsive to local needs and desires (CQS, 2012; 2013).

This paper examines why such a concern exists in the Netherlands - a nation recognized worldwide as a roadmap towards efficient protection against structural flooding - from a historical perspective. It describes, firstly, the physical form urban flood control took on in stages by describing representative examples. Secondly, it explores what drove those changes. To do so, I explicitly consider changes in the way flood control has been organized, planned and financed.

This paper is focused exclusively on those flood control measures aiming to prevent flooding caused by storm surge. As a result, the geographical scope of study is also limited to areas subject to storm surge flooding, and covers the coastal arcade of the Netherlands including the tidal inlets of the Rhine-Meuse delta. It covers flood control measures in coastal settlements from the navy town of Den Helder in the north to Flushing in the south.

The study describes the major changes in urban flood control since 1800 in three phases. In many scientific works phases in the way the Dutch have dealt with the threat of flooding since the middle ages have been identified, like Van der Ham (2002), Van Dam (2010), Hooimeijer (20II) and Meyer et al. (20l3). According to Van der Ham (2002) the Dutch developed a manipulative attitude after the 1800 s, after three centuries where the common attitude could be labeled as offensive. Until the $16^{\text {th }}$ century Dutch efforts had been defensive, primarily aiming to prevent land destruction. Hooimeijer (20I I) elaborated on this approach by dividing the manipulative phase in three sub-periods, based on major changes in the disciplines of engineering and urbanism: 1800-1890 (offensive), 1890-1990 (manipulative) and after 1990 (adaptive-manipulative). For engineering, the main divide lies at the 1990s, when the industrial mode of production gave way to the post-industrial one. For urbanism, this is the period where modernism gave way to postmodernism. As it's likely that these three periods collide with major changes in the organization of urban flood control, this paper will follow these as well.

\section{|800-|890 A REGIONAL APPROACH}

Gradual erosion of the coast and inland patches of land continuously threatened Dutch settlements since the middle ages, when the low-lying marshes of the Netherlands were first cultivated. A complex of drivers like sea level rise, subsidence and peat harvesting caused substantial and accelerating land loss. As early as the $14^{\text {th }}$ century landowners and other stakeholders joined forces in order to erect levees and dikes, followed by the construction of windmills to pump out excess water in the I500s (Stive \& Vrijling, 20I0).

“Voor de deur ligt een Atlantikwall, was dat nou nodig?", in: Volkskrant, september, I4, 2013. 


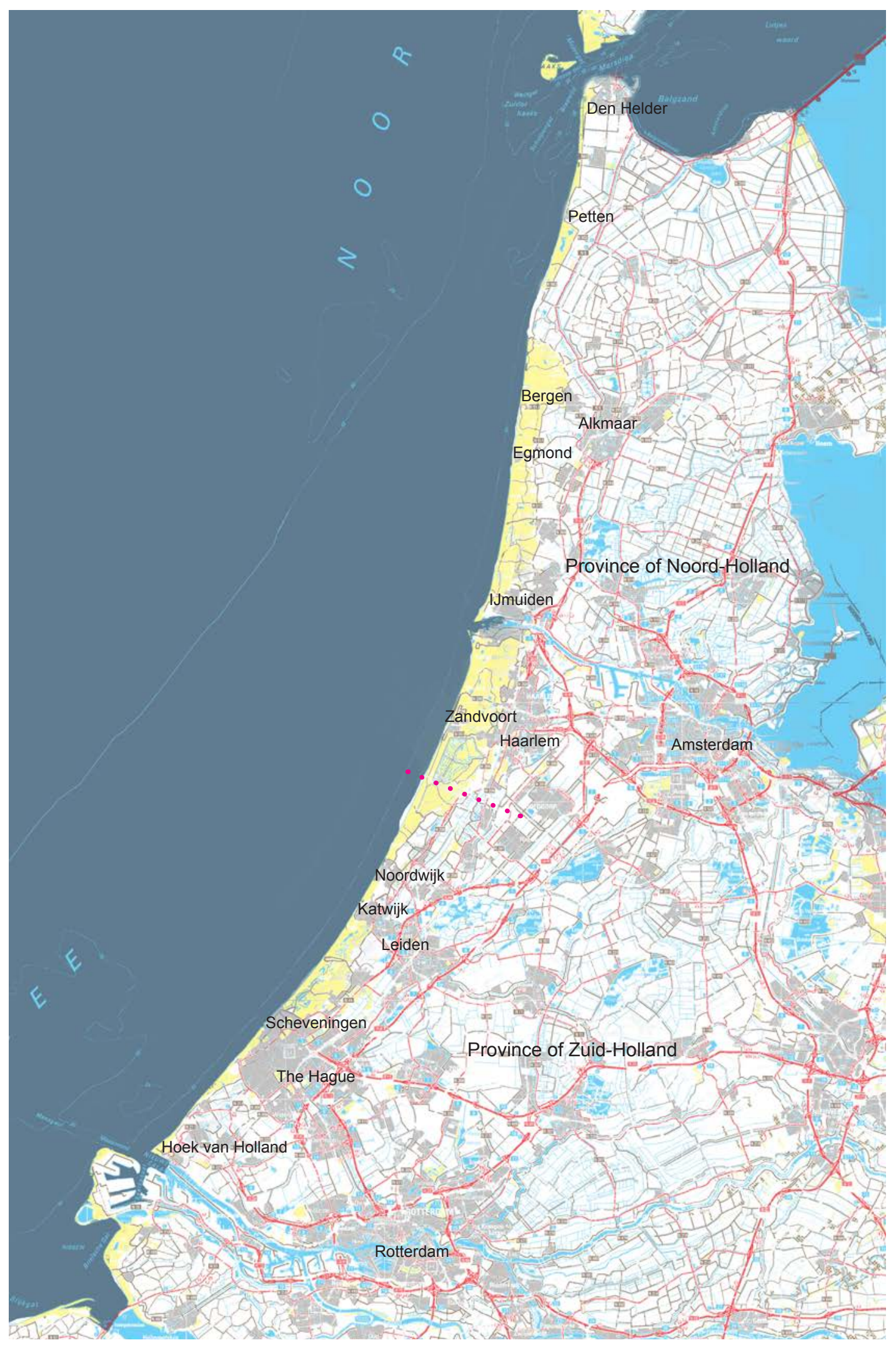

Figure I. The Dutch coast and delta with its settlements Source: Coastal Quality Studio suministrated by author, N. Brand, 2014. 
The organizations needed to maintain such public works were called waterboards. Size and style of management differed from region to region, with cities taking separate chairs within the executive board of daily management (De Monté Verloren \& Spruit, 1982). The waterboards - a form of special-purpose government - developed simultaneously with, yet independently from, general-purpose local governments common to medieval Europe like localities and counties. They collected their own taxes, either in cash or kind, appointed their own officials, and administered justice towards those threatening the protection of their territory against flooding.

As a result, a systematic approach towards flood control existed before 1800 , albeit on a regional basis. As a variety of waterboards took the lead in the organization of regional interests with respect to flood control, the appearance of flood control measures seems to have differed from place to place. Earthen dikes, made out of clay, dominated everywhere but the revetment varied from packages of straw, seaweeds or protective rows of poles (Van der Woud, 1987). Cities and settlements developed primarily in the hinterland, with trade and industry flourishing where flood protection measures like dams required transshipment of goods. Before the $19^{\text {th }}$ century true waterfront towns and cities only existed where the opportunity of fast economic profit compensated for the risk of flooding (Meyer, 20I0).

As such cities were thriving on international trade, their waterfronts were typically in use for the purpose of shipping. Amsterdam (which experienced accelerated expansion from the late $15^{\text {th }}$ century) and Rotterdam (from the $18^{\text {th }}$ century onwards) are the largest examples. Both cities are not located on the sea, but respectively on an inland sea and within the estuary of the Meuse. These cities dealt with the tidal movements of the sea and salt or brackish waters, whereas most other harbor towns in the Netherlands were located on fresh bodies of water.

Although no exhaustive inventory of historic urban flood defenses exists, it seems that for most harbor cities - those bordering on the inlets of the rivers Meuse and Rhine, or on the inland Southern Sea - a combination of an earthen (clay) dike with a protective row of poles was the norm. Such flood defenses are seen on historic townscapes and maps. Often, the entire waterfront was raised by the use of landfill (Rutte, 2006). Such was the case for Dordrecht, where the entire waterfront was elevated. In Amsterdam a dike protected the city itself. Rotterdam's waterfront - the harbors - was elevated as well (Meyer, 2010). Possibly the ramparts double-functioned as a flood defense as well.

Flood protection of such waterfronts was likely controlled by city government, as in the early modern age such local governments were independent and powerful political entities. The city of Leiden, for example, organized all measures on behalf of water management within its perimeter, as long as this did not intervene with the regional plans of the waterboard (Van Tielhof \& van Dam, 2006). Outside of the city proper, the waterboards reigned.

The coastal zone itself was generally avoided - which meant that coastal protection was only required wherever the coastal dunes were too thin to prevent coastal surge from flooding the hinterland. An example of such a project was the Hondsbossche Zeewering, for which a stakes-and-thatch combination was used (CQS, 20I3).

It seems such a regional distribution of responsibilities, based on strong local government, was moderately successful until the second half of the $18^{\text {th }}$ century. From thereon, severe flood events were frequently reported (Van der Woud, 1987): in I73I, I 775 and I 825. This was caused by a combination of drivers. First of all, economic hardship undermined the 
means to provide effective flood protection. Secondly, the introduction of the shipworm, a foreign species, rendered the use of constructions using wood for flood control obsolete. The worms caused tremendous damage to flood defenses throughout the Netherlands.

A discernable response to these flood risk challenges waited until the early $19^{\text {th }}$ century. This response can be labeled as the parallel rise of increasingly uniform dikes and the introduction of stone boulevards and as a means of urban flood control (Van der Woud, 1987). Boulevards were constructed in Scheveningen, Zandvoort and Domburg. The architecture of the waterfront was dominated by the typical eclectic neo-styles that emerged throughout Europe, and housed functions like exclusive hotels, salons, restaurants and spas (Denslagen, 2004; Stenvert, 2004). Boulevards were constructed with an outer revetment of stone while earth and clay dikes with stone or basalt revetments became the norm elsewhere. In I880, a dike also replaced the stakes-and-thatch construction of the Hondsbossche Zeewering.

Three main drivers can explain both the timing and the dramatic change in the shape taken on by the flood defenses. First of all, from the early decades of the $19^{\text {th }}$ century, the coast was discovered as a destination for a new type of economic activity: recreation for the privileged classes. In response, resorts developed in the coastal zones throughout Europe and beyond, often equipped with a boulevard to stroll on in one's best outfit (CQS, 20I3).

For the first time in centuries, the lure of the sea drove settlements into flood prone areas earlier considered too dangerous for permanent use. This not merely required the protection of valuable buildings and businesses against flooding, but also in a shape that warranted the competitive advantage of coastal resorts: the attractive strolling environment provided by a boulevard. The boulevards were constructed in order to provide the best possible view of the sea, and a more comfortable walk than the natural beach would allow.

A third driver behind the dramatic change in the shape and appearance of urban flood protection measures was the geographic upscaling of water management that came with the rise of the Dutch national state. Although the Kingdom of the Netherlands had been declared in 1814 , centralization truly gained momentum after the 1850 s. At first, national water management efforts concentrated on the navigability of the Rhine-Meuse delta, a matter of economic survival for the new state: the navigability of the Rhine-Meuse delta (Meyer et al., 20I3). As navigability and flood protection went hand in hand here, both were considered to be a national responsibility par excellence.

To address water management issues - a task of utmost national importance according to the national constitution (Van der Woud, 1987), just behind defense of the nation against foreign enemies - a national Corps of Engineers was erected (Bosh \& Van der Ham, 1998). The Corps of Engineers concentrated outstanding expertise, employed wherever national interests were at stake, or where the funds or expertise of the regional waterboards were unable to sustain spatial interventions. Initially, the efforts of the Corps focused on continuing the Dutch tradition of offensive water management: reclaiming land that was lost to large inland lakes. One of its earliest feats of arms was the reclamation of the Haarlemmermeer, a large inland lake of which the water was lapping unto the ramparts of Amsterdam under storm conditions.

The centralized efforts of water management and flood protection had a severe impact on the appearance of urban flood protection measures, but also on the growth and specialization of urban communities in the Netherlands. The construction of the Nieuwe Waterweg (I872) at the city of Rotterdam altered the distribution within the tidal inlets of the delta 
significantly. And the fact that $55 \%$ of the river water was expelled via Rotterdam gave the city a significant competitive advantage for trade and shipping, which soon translated into feverish building activities (Meyer et al., 2013). While Rotterdam turned into the primary national harbor, the construction of a harbor and boulevard for coastal resort Scheveningen by the Corps in the early $20^{\text {th }}$ century, contributed to its dominance above other resorts in the Netherlands.

Additionally, the national state increasingly employed efforts to incorporate the regional and yet independent waterboards. As this met with resistance, and the waterboards possessed crucial local expertise that could not be replaced by the Corps immediately (Van der Woud, 1987), the national state settled for setting legal requirements to which waterboards had to comply. This contributed to the standardization of technical design standards for flood protection measures nationally. Under the scrutiny of the Corps - which controlled and maintained most of the flood defenses considered to be of primary importance, like the coastal and riverine dikes - the Dutch approach of flood control did become more systematic.

Although flood events continued to occur until the second half of the $20^{\text {th }}$ century, there was some general success in reducing their number. Impressive amounts of land were reclaimed using stream power. The waterboards kept their independent tax-base and the right to appoint their own staff, but otherwise a lot changed in the distribution of responsibilities concerning flood control. The waterboards themselves lost their capability to administer justice. Other local entities, like city governments, completely left the stage. Increasingly, they became dependent on the efforts of specialized water authorities.

\section{I890-I 990 NATIONAL STANDARDIZATION}

After the 1890s, the Dutch attitude towards water management turned from offensive to manipulative. The approach to flood control did not merely become more efficient in diminishing the detrimental effects of flood events; it also became more thorough and far reaching. Spatial interventions were no longer confined to those spots where flood control was needed most. Instead, the entire water system was altered and modified to meet required protection standards demanded by national law.

The 1890-1990 period in the Netherlands is mostly known for its great achievements in hydraulic engineering and water management. However, it was also the era when all flood defenses considered as primary to the nation's protection against flooding were heightened to so-called 'delta altitude', and when virtually all the coastal resorts lost their charm.

In the organization, planning and finance of flood control measures the national Corps of Engineers became more dominant, building on the changed distribution of responsibilities that resulted from the $19^{\text {th }}$ century.

In the first half of the $20^{\text {th }}$ century centralization became manifest in two ways. The regional waterboards became increasingly subject to the requirements and standards of national government, and the first grand projects were executed. The Southern Sea Works (19201968), an impressive scheme that turned the rebellious inland sea into a freshwater lake, was developed in response to a large flood in 1916. The plan also shortened kilometers of primary sea defense to be maintained by the Corps of Engineers. For its execution a separate central office was erected: the Corps was considered to be too conservative for the construction of such daring measures (Bosch \& van der Ham, 1998). 
The effect on waterfronts varied. For waterfront cities located on the shores of the former Southern Sea, like Amsterdam, it meant that they no longer had to deal with the challenges of salt water and tidal movement. Obviously some kind of protection was still needed to deal with wind set up in the new lake, but not up to the levels required for storm surge in large open waters. For waterfront settlements like the naval town of Den Helder in the north, the Southern Sea Works resulted in an additional challenge: accelerated coastal erosion. All things considered, this meant that waterfronts like Amsterdam's were released from the future interference of the Corps that those bordering on a primary flood defense would have to deal with.

However for many waterfronts the impact of nationalized flood control yet had to reach its zenith. In many ways, the 1950s form the true milestone in the historic development of especially the coastal settlements. The traumatic flood of 1953, increased centralization and national planning, unprecedented population growth and the introduction of new technologies in the aftermath of the Second World War contributed to a dramatic change in the appearance of the Dutch waterfronts.

The overall effect of this dramatic change can be summarized as follows: flood control measures, especially those considered to be of primary concern (and therefore, under direct management of the Corps), became increasingly standardized, explicitly single-purpose, higher, broader and surrounded by land use restrictions in order to warrant space for future broadening. Often, this not only resulted in the loss of the desired direct view to the open waters. It also turned the land in the direct vicinity of the flood defense into a spatial limbo; a no-mans-land removed from the daily operation of the towns behind them by a higher authority that was hard to reach for the concerns of local government.

In this manner, waterfronts increasingly came to look alike and most lost their appeal. This was especially painful for the waterfronts of towns that depended on tourism entirely, like Zandvoort, Katwijk, Noordwijk and Scheveningen (Steenhuis, 20I3).

The conditions for this dramatic shift were laid in the first half of the $20^{\text {th }}$ century. In spite of the increased influence of the Corps and the Southern Sea Works, one could say that the flood risk - the chance times the consequences of a flood event - in general increased in the early decades of the $20^{\text {th }}$ century. Widespread, ongoing urbanization and lack of structural funding opportunities for flood control developed hand in hand. Many cities grew beyond their ramparts (which were usually demolished) into deeper flood prone areas. The centuries-old phenomenon of subsidence continued, accelerated by mechanical drainage. Coastal resorts arose in former fishing settlements like Katwijk and Noordwijk, directly on the beach. In Scheveningen urban expansion continued into the dunes, and an outer harbor was constructed between 1900 and I9II.

While some areas expanded, exposing ever more livelihoods to the danger of a flood event, others marginalized and lost the means to maintain flood protection standards. The rise of large port-cities with their expansive harbors, transfer sites, rail yards and related industries and services (insurance and banking), like Rotterdam and Antwerp in nearby Flanders, soon overshadowed the smaller port-towns on the isles of the southwestern delta, where agriculture remained the dominant economic activity. As a result funding for maintenance of the dikes diminished (Meyer et al., 20I3). 
The global economic crisis of the 1930s and the German occupation in the early 1940s did nothing to improve the increasing mismatch between the required flood control measures and the available funding. The flood of 1953 that claimed I 500 fatalities in the southwestern delta, demonstrated the need for intervention in the most painful way.

Like the Southern Sea Works, the Delta Works (1953-1986/1997) aimed to shorten the coastline significantly, so as to diminish the lengths of flood defense to be maintained on the highest safety level. In both cases the policies supporting the grand works were synchronized at the national level with economic and spatial policy aims. For the Delta Works, this included the advancement of the isles of the southwestern delta via improved accessibility and fresh water supply to increase efficiency in agricultural production. The project included the construction of dams on all tidal inlets, with two exceptions: the storm surge gates at the Meuse and the Eastern Scheldt river. Both the argument that the grand works did more than just provide protection, and the promise of future economic profit, were needed to convince the House of Parliament to commit the required funds and political support (Kothuis \& Brand, forthcoming). ${ }^{2}$

The flood of I 953 heralded what has been dubbed 'a safety doctrine' in the Netherlands. After the construction of the Dutch grand works, the nation remained undisturbed by flood events for decades. In a flush of victory the lasted at least two decades, Dutch hydraulic engineers became national heroes, and the merits of flood control measures above question (Heems \& Kothuis, 2012). In sharp contrast with the grand works - which had to be justified to the House of Parliament by pointing out its 'multi-purposeness', both funding and political support for spatial interventions on behalf of flood control were given without second thought.

In combination with the grand works, the entire first line of protection had to be raised to 'delta-altitude'. For example, the $6 \mathrm{~km}$-dike of the Hondsbossche Zeewering - a former sanddike that was covered with revetments of basaltic blocks in 1880 - was raised to I 1.5 meters above mean sea level. A comparable gigantic structure arose in Den Helder, where it dwarfed the town and removed the sea from sight entirely. Wherever the dunes were considered insufficient, they were strengthened with extra sand and planted with beach grass. In this manner the Dutch coast, which had relocated itself dynamically over the centuries, was fixed along a precise location, bringing coastal erosion to a standstill. The finishing touch of this practice was achieved in 1990, when the Basal Coast Line was recorded in a separate Act.

However, the increased urgency to intervene on behalf flood control was not the only driver for the dramatic change that manifested itself on waterfronts hosting primary flood defenses. The shape taken on by spatial transformation was for a large part determined by post-war planning-doctrine (Faludi \& Van der Valk, 20I0), which ranged from large-scale flood control systems like the Deltaworks, to pro-active policies on agriculture, industry and spatial planning. According to Meyer et al. (2013) the approach of the post-war planningdoctrine was implicitly reductionist. To facilitate governmental intervention on a wide range of issues complex spatial and societal phenomena were reduced to manageable and often mono-functional spatial units that could be designed, managed and financed separately.

2 This is a preview of a paper ('Multifunctionele waterkeringen en legitimiteit') written in collaboration with B. Kothuis for the Dutch magazine Watergovernance. 
As a result, the post-war planning doctrine primarily contributed to the decreased attractiveness of Dutch waterfronts in two ways. The occupation by German forces between 1942 and 1945 had created the perfect conditions for a tabula-rasa approach. Everywhere, $19^{\text {th }}$ century waterfronts had been demolished in favor of the concrete fortifications of the Atlantikwall. Worse, the city of Rotterdam had been carpet-bombed, preparing it for that next wave of architecture fashion: modernism (Denslagen, 2004). National reconstruction policies, aiming to house a booming population as fast and efficient as possible with limited financial means, replaced the demolished buildings by constructions with a uniform and sober architecture (CQS, 20I3).

In the practice of flood control, the post-war planning doctrine manifested itself as well. While the post-war reconstruction issue was addressed by the Ministry of Housing, the Corps of Engineers financed, planned and executed it's own spatial interventions separately. The waterboards, responsible for the maintenance of some of the national and all of the other flood defenses, warranted damage to the construction by restricting possibilities for co-use in their policies (Van de Sande, 2009).

So after an initial period wherein the legitimacy of large-scale spatial interventions on behalf of national flood control was still un-established, after the 1960s the prevalence of Dutch hydraulic engineering above all other spatial considerations was above question for several decades. It was in this era that the foundations for resistance against uniform and single-purpose flood control measures were laid.

By the 1990s the Dutch Delta resembled an impregnable fortress. This altered the experience of the coast, and of coastal resorts specifically, in an extreme way. Waterfront communities often lost their most important spatial asset: direct access to the sea. They were also faced with building restrictions and land use limitations on, and in the vicinity of the flood defense. This caused a general sentiment that flood control was a necessary evil: a sacrifice of spatial qualities in order to diminish flood risk.

\section{AFTER THE I990S NATIONAL DIVERSIFICATION}

From the 1990s on, the practice of flood control changed significantly. In 1995, several experiments started with so-called dynamic coastal management. This resulted in pilot projects like De Kerf (1997) and later the Sand Engine (20II). At The Kerf, the sea was allowed to enter a designated coastal area in order to create a natural landscape to stimulate recreation. The Sand Engine demonstrated how excess sediment supplementation on a strategic location allows the alongshore current to distribute sand along the coast. In this manner, flood risk is addressed not merely without disturbing the natural environment, but by using the forces of nature to do so (Stive \& Vrijling, 2010).

Deeper within the Dutch Delta, such pilot projects received a riverine counterpart in the shape of the 'Room for the river'-program. Instead of heightening and broadening the flood defenses bordering the riverbed, the riverbed itself was widened to allow the river to run its course in a more natural way (Stive \& Vrijling, 20I0).

For the waterfronts, this new approach towards flood control manifested itself in the introduction of so-called 'hybrid' flood defenses: the dike-in-dune constructions in seaside resorts like Noordwijk and Katwijk, and the dike-in boulevard of Scheveningen (Brand, 20I2; CQS, 2013). Obviously, the use of several materials in the construction of a flood defense 
was nothing new; but the fact that constructions are wrapped with a certain material to make it appear like something else for cosmetic reasons, was.

Overall, the spatial interventions on behalf of flood control share several properties. These can be summed up as follows: implemented with respect for the natural environment; employing the forces of nature if possible; and executed in such a way that the flood defense merges with its context, or is cosmetically altered to go easy on the eyes (CQS, 20I3).

Additionally some of these projects were explicitly aimed to fulfill several purposes in one spatial intervention. The dike-in-boulevard in Scheveningen diminished flood risk but improved the public space and boosted the business of neighboring hotels and restaurants. The dike-in-dune at Katwijk - currently under construction - also houses a garage, moving parked cars from the urban surface above.

The diversification and increased multifunctionality of flood control measures in the Netherlands can be understood by looking at changing planning doctrines, and the issues that drove such change (Meyer et al., 20I3).

First off, riverine floods and near-floods in 1993 and 1995, led to the policy-aim to prepare the rivers for higher peak discharges, from $12.000 \mathrm{~m}^{3}$ to $16.000 \mathrm{~m}^{3}$ per second. This could not be achieved without widening the riverbed itself. House of Parliament enacted a new set of acts in order to assess and address the protection standards of primary (national) flood defenses (Driesprong, 2004) including those along the coast.

Secondly, planning procedures in the Netherlands had changed significantly. That spatial intervention on behalf of flood control could no longer be accomplished without taking into account public resistance on behalf of environmental values had been demonstrated as early as 1974. After severe pressure in the media, House of Parliament ordered the Corps of Engineers to come up with a half-open storm surge gate for the Eastern Scheldt River, instead of just closing off the estuary with a dam (Bosch \& van der Ham, 1998).

Although the nature conservation movement was the first to push its concerns, it was by no means the last (Stive \& Vrijling, 20I0). Public resistance manifested itself increasingly in all spatial plans alike; and through several Planning Acts, local governments were required to organize public participation before granting permits. These acts aimed to empower local stakeholders and give local interests a say in zoning plans. Additionally local governments were forced to comply with an ever-increasing set of policy requirements from national, and eventually, European levels of government.

As a result, planning procedures became increasingly complex, elaborate and lengthy, taking into account multiple considerations before reaching implementation. Although this frustrated speedy planning, it also allowed the increased public appreciation for natural values and spatial qualities to play a role in the practice of flood control. Likely, the change in planning doctrine and practice is the main driver behind the diversification of flood control measures in the Netherlands.

I suspect that elaborate planning procedures are also the primary motivation behind the renewed multifunctionality of Dutch flood control measures; and the increased demand for them. However, in sharp contrast with the 'multi-purposeness' of the Dutch grand works, multifunctional flood defenses like the boulevard in Scheveningen or Katwijk were 
not designed with the primary aim to recoup the costs of implementation. In fact, the extra purposes often seem to cost money rather than to make it.

Likely, this is because the additional purposes were chosen throughout the planning process in order to convince local stakeholders to cooperate. Though slow and costly, this phenomenon also leads to flood control measures that are responsive to the needs of local communities. And on a larger scale (and long term) to the diversification of Dutch waterfronts.

\section{CONCLUDING REMARKS}

Over the vast majority of the decades stretching from 1800 until today, flood control in the Netherlands has been planned, financed, executed and maintained in a highly centralized manner. This explains largely why flood control measures appear to be uniform and standardized, and also initiatives for spatial interventions on behalf of flood control meet with local public concern. However, since the 1990s the times seem to have changed for waterfront communities. Although the initiative to raise the safety standards of (national) flood defenses still comes from national government, spatial interventions are becoming more diverse, multifunctional and catered to local interests. This demonstrates that though flood control in the Netherlands is still centralized, that does not necessarily mean that measures that improve flood control have to be uniform and standardized.

Apart from centralization in the organization of protection against flooding, change in flood control in urban waterfronts in the Netherlands has been driven by other factors as well. Although such drivers merit to be analyzed more thoroughly, here l'll suffice with naming the three most obvious ones: increased urgency, available means and cultural preferences. Increased urgency resulted from a combination of factors in the natural environment on the one hand, and intensified use of the flood zone by mankind on the other. The flood events that almost inevitably resulted from increasing risk kick started changes in flood control measures. Once urgent, change in flood control was then influenced by a second driver: the means, including economic resources and available technology. These drivers decided on the range of possible flood control measures. Last but not least cultural preferences played a role. These impacted the exact design and execution of the flood defense structure, and therefore the appearance of flood control measures in urban waterfronts.

\section{REFERENCES}

Bosch, A. \& W. van der Ham. (1998). Twee eeuwen Rijkswaterstaat I 798- 1998. Zaltbommel.

Brand, N. (ed.). (2012). European references. International workshop on coastal quality. Delft.

Carasso-Kok, M. (ed.). (2004). Geschiedenis van Amsterdam. Tot 1578. Een stad uit het niets. Amsterdam.

Coastal Quality Studio. (2013). Safety and quality for the Dutch coast: towards 2100. Delft.

Denslagen, W. (2004). Romantisch modernisme. Amsterdam.

Driesprong, A. (2004). Water, gemeenschappen en waterschappen. Wettelijke taken en bevoegdheden in het regional waterbeheer. Den Haag.

M 49 REVISTA M VOL. 11 No.1. ENERO-JUNIO 2014 • FACULTAD DE ARQUITECTURA • UNIVERSIDAD SANTO TOMÁS COLOMBIA 
Faludi, A. \& A. van der Valk (2010). Rule and Order. Dutch planning doctrine in the twentieth century. Dordrecht/Boston/London.

Heems, T. \& B. Kothuis (20I2). De mythe van droge voeten.

Hooimeijer, F.L. (20I I). The tradition of making polder cities. Delft.

Kothuis, B. \& Brand, N. (forthcoming Watergovernance) 'Multifunctionele waterkeringen en legitimiteit. De institutionele achtergrond van het streven naar functiecombinatie met waterveiligheid'.

Meyer, H. (2010). 'Composition and construction of Dutch Delta Cities', in: H. Meyer, I. Bobbink \& S. Nijhuis (eds.) Delta Urbanism. The Netherlands. Chicago/Washington DC, pp. 64-99.

Meyer, V.J., van den Berg, J., Bregt, A.K., Broesi, R., Dammers, E., Edelenbos, J., Nieuwenhuijze, L. \& Roeleveld, G., Meyer, G. (20I3). Nieuwe perspectieven voor een verstedelijkte delta. Naar een method van planvorming en ontwerp. Delft.

Monté Verloren, PH de \& Spruit, J.E., (1982). Hoofdlijnen der ontwikkeling der rechterlijke organisatie in de Noordelijke Nederlanden tot de Bataafse omwenteling. Deventer.

Rutte, R. (2006). 'Groei en krimp van de Hollandse stad', in: Overholland 3, pp.29-56.

Sande, C.M. van der (2009). Design of a Dutch superlevee. Delft. 
Steenhuis, M. (2013). De cultuur van de Nederlandse kust: durf te differentieren, in: Atelier Kustkwaliteit, Ecologie, cultuur en economie van de Nederlandse kust. Delft.

Stenvert, R. (ed.) (2004). Monumenten in Nederland. Zuid-Holland. Zwolle.

Stive, M. \& Vrijling, H. (20I0). 'Draining, dredging, reclaiming: the technology of making a dry, safe and sustainable delta landscape', in: H. Meyer, I. Bobbink \& S. Nijhuis (eds.) Delta Urbanism. The Netherlands. Chicago/Washington D.C., pp.20-43.

van Dam, P.J.E.M. (20I0). Cities and flood control: the amphibious culture in the Netherlands before 1800. Introduction and Paper presented at the plenary openings panel Perception and Management of Disastrous Floods of the conference of the International Water History Association, Delft University of Technology, 17 June 2010.

van der Ham, W. (2002). De Historie. In: van Buuren, M. (ed.) Waterlandschappen, de cultuurhistorie van de toekomst als opgave voor het waterbeheer. Lelystad.

van Tielhof, M. \& van Dam, P.J.E.M. (2006). Waterstaat in stedenland. Het hoogheemraadschap van Rijnland voor I857. Utrecht.

Woud, A. van der (1987). Het lege land. De ruimtelijke orde van Nederland I798-/848. Amsterdam. 